\title{
Mechanisms of Social Capital in Organizations: How Team Cognition Influences Employee Commitment and Engagement
}

\author{
Alexander Kroll, Florida International University, Miami, USA \\ (https://orcid.org/0000-0002-2825-8607) \\ Leisha DeHart-Davis, University of North Carolina, Chapel Hill, USA \\ (https://orcid.org/0000-0001-9406-3851) \\ Dominik Vogel, University of Hamburg, Germany \\ (https://orcid.org/0000-0002-0145-7956)
}

This is the post-print of the following article: Kroll, A., DeHart-Davis, L., \& Vogel, D. (2019). Mechanisms of Social Capital in Organizations: How Team Cognition Influences Employee Commitment and Engagement. American Review of Public Administration, 49(7), 777-791. https://doi.org/10.1177/0275074019851894 


\begin{abstract}
While previous research has shown that organizational social capital benefits organizations and creates performance gains, most of this work examined this relationship at the macro level based on organizational aggregates. In this article, we study organizational social capital effects at the micro level, that is, its impact on important work-related attitudes of employees within organizations. We argue that individual perceptions of organization-wide social capital matter in determining employee attitudes like engagement and commitment. We also point to the critical role of team cognition in shaping individual perceptions of social capital in organizations. Using a representative sample of nearly twelve hundred individuals from two local government organizations in North Carolina, we find support for the indirect effect of team cognition on employee work attitudes. The findings suggest that a promising way to increase the social capital of organizations is through interventions at the team level.
\end{abstract}

Keywords: Organizational social capital; Commitment and engagement; Team mental models and cognition; Public-sector organizational behavior 


\section{Introduction}

Social capital is a collective resource made up of collaboration, trust, and a sense of mission among members within organizations (Inkpen \& Tsang, 2005; Nahapiet \& Ghoshal, 1998). Private sector research has shown that firms with more social capital develop favorable organizational attributes that help create an advantage over other firms (Chow \& Chan, 2008; Clercq, Dimov, \& Thongpapanl, 2013; Sherif, Hoffman, \& Thomas, 2006; Tsai \& Ghoshal, 1998). Similarly, public sector research has shown that the social capital of public organizations is positively related to organizational performance, although such an effect can be nonlinear, mediated, and disproportionally beneficial to certain client groups (Andrews, 2010; Compton \& Meier, 2016; Holme \& Rangel, 2012; Leana \& Pil, 2006).

Despite clear evidence regarding performance effects at the macro level, little is known about the specific mechanisms through which the benefits of social capital materialize within organizations. In particular, relatively little research examines the internal organizational variables that subtract or add social capital, or how organizational social capital affects individual outcomes that potentially improve performance. This article's first contribution is that it sheds light on the mechanisms ${ }^{1}$ at the micro-level that may help further explain the connection between social capital and organizational performance: how organizational social capital is linked to the work engagement and organizational commitment of members within public organizations. The article's second contribution is that it examines the importance of teams in the process of translating social capital into positive employee-level outcomes. Work groups often

\footnotetext{
${ }^{1}$ The causal claims we make in this paper are based on theory and correlational analysis. We do not infer causality just from the analysis, which would require the use of randomized experiments.
} 
constitute prisms through which employees view the entire organization, and social interactions with team members shape individual perceptions of the work environment.

Our theory is concerned with the perceptions of organization-wide social capital by individual employees, who constitute our unit of analysis. Drawing on organizational behavior theories of teams and learning (e.g., Mohammed, Ferzandi, \& Hamilton, 2010; Rentsch \& Klimoski, 2001; Wong, 2004), we argue that team cognition with regard to organizational social capital shapes team members' social capital perceptions. That is, employees' understanding of the social capital in the organization they work for is a function of the social interactions within their work groups. In a second theoretical step, we argue that individuals' perception of the presence of organizational social capital fosters positive work-related attitudes like engagement and organizational commitment. In particular, we propose that social capital increases engagement and commitment because it creates intra-organizational networks that allow members to become more effective; reduces transaction costs of interactions by building trust; and creates a sense of joint purpose and organizational cohesion (e.g., Chughtai \& Buckley, 2013; Kim \& Rhee, 2010; Kristof-Brown, Zimmerman, \& Johnson, 2005; Kroll \& Tantardini, 2019).

Overall, we find empirical support for the indirect effect we propose: Team mental models of social capital are expected to magnify individual capital perceptions that, in turn, affect individual-level attitudes like engagement and commitment. Given the role of team cognition in forging employee attitudes, our results suggest that public managers should focus on developing collaboration, trust and a mission focus within teams. 
In what follows, we offer a definition of the organizational social capital concept and lay out our theoretical argument in greater detail. To test our hypotheses, we use an organizationally representative sample of nearly 1,200 individuals from two local government organizations in North Carolina. After explaining our data and methods, we display the statistical findings, discuss them, and distill our major conclusions at the end.

\section{Defining Organizational Social Capital}

While definitions of social capital vary in breadth and depth, one common conceptual thread is the structure and quality of relationships between organizational members (Adler \& Kwon, 2002; Leana \& Van Buren III, 1999). Along these lines, social capital has been described as the goodwill that comprises sympathy, trust, and forgiveness (Adler \& Kwon, 2002); networks, norms and social trust (Putnam, 1995, p. 67); and structural elements of organizations that affect relationships between people (Schiff, 1992, p. 160). The quality of these relationships comprises social capital, which is construed as an attribute of organizations (Coleman, 1990, p. 302; Putnam, 1995, p. 67; Schiff, 1992, p. 160).

Social capital serves three theoretical functions within organizations: it facilitates cooperation among organizational members (Coleman, 1990, p. 302; Portes \& Sensenbrenner, 1993, p. 1323; Putnam, 1995, p. 67), it reduces the need and costs to monitor behavior (Leana \& Van Buren III, 1999), and it speeds the transfer of knowledge (Nahapiet \& Ghoshal, 1998). Given this range of functions, it is not surprising that scholars have cast organizational social capital as an asset to organizations, joining the ranks of physical and human capital (Leana \& Van Buren III, 1999, p. 539). 
Since the introduction of the social capital concept in the mid-1990s, scholars have identified three types of social capital: structural, relational, and cognitive. The structural dimension of social capital pertains to the configuration of relationships within organizations, either between individuals or groups. Nahapiet and Ghoshal originally cast structural social capital as an impersonal characteristic of networks within organizations (1998, p. 244). Andrews subsequently focused on the extent of collaborative relationships in the organization (2010, 2011). Drawing on literature related to networks and learning, he argued that collaborative structures increase contact between individual and work units which, in turn, expedite the flow of organizational information (Kogut \& Zander, 1996), hasten organizational learning and knowledge accumulation (Nahapiet \& Ghoshal, 1998) and increase cooperation between organizational members (Miller, 1992).

The relational dimension of organizational social capital focuses on the quality of relationships between actors. These relationships are built over time through interactions between individual organizational members (Nahapiet \& Ghoshal, 1998, p. 244). Relationships high in trust, loyalty, obligation and identity are expected to create solidarity in the workplace (Adler \& Kwon, 2002). That solidarity, in turn, is expected to loosen the flow of information, enhance cooperation and reduce the need for monitoring (Nahapiet \& Ghoshal, 1998). Ultimately, organizations high in relational capital are expected to have greater organizational commitment (Andrews, 2011), lower employee turnover (Dess \& Shaw, 2001), and ultimately higher performance (Andrews, 2010).

The cognitive dimension of organizational social capital relates to collective understandings that emerge from organizational membership. These understandings create representations on organizational phenomena that are shared by organization members, that 
allow for common interpretations of events and behavior, and that create systems of meaning (Nahapiet \& Ghoshal, 1998, p. 244). A number of organizational mechanisms are thought to inform these understandings, including mission and values (Andrews, 2010, 2011); goal clarity (Holme \& Rangel, 2012) and leadership turnover (Dess \& Shaw, 2001; Holme \& Rangel, 2012). Cognitive social capital is theorized to reap a host of benefits for organizations, including organizational identification, a shared language for diffusing knowledge across diverse units (Nahapiet \& Ghoshal, 1998), organizational stability (Holme \& Rangel, 2012), and motivation for collective action (Andrews, 2010, 2011; Leana \& Van Buren III, 1999).

The dimensions of organizational social capital are conceptualized as distinct, but it is easy to foresee interdependencies. For example, structural capital inevitably will logically affect knowledge and learning, as certain group configurations can impede information flow and collaboration (Andrews, 2010, p. 601). Structural capital has also been linked with facets of relational capital (Nahapiet \& Ghoshal, 1998, p. 251). While the exact linkages have not been fully mapped out, we recognize the potential interdependencies. We therefore conceptualize organizational social capital as a hierarchical latent construct that at the first level consists of three sub-dimensions, which however share enough similarities to make up a joint social capital factor at a higher level.

\section{A Micro-Perspective of Social Capital in Organizations}

\section{Conceptual Clarifications}

A micro-perspective on organizational social capital is concerned with its impact on members of the organization. If social capital benefits organizations at the macro level, then we 
should be able to see parallel causal mechanisms at the micro-level that would help explain the macro effect (Kozlowski \& Klein, 2000). In particular, we assume there should be an effect of organizational social capital on important work-related employee attitudes and behaviors.

In this study, we examine specific effects on employees' work engagement and organizational commitment, and we selected these outcomes variables for three reasons: both variables are important antecedents of organizational performance; they both tap into positive attitudes towards one's work, yet are conceptually and empirically distinct from each other; and they can be measured using tested and validated scales (Balfour \& Wechsler, 1996; Halbesleben, 2010; Hallberg \& Schaufeli, 2006; Meyer, Stanley, Herscovitch, \& Topolnytsky, 2002). Cumulatively then, both variables constitute promising proxies to examine the behavioral (micro-level) impact of organizational social capital. That is, while social capital effects may not be limited to the two variables we study here, we think that social capital - if influential - should display a positive impact on employees' engagement and commitment; and we explain the logic behind this reasoning in the section below.

At the same time, both engagement and commitment are different enough from the social capital construct, so that our hypotheses about a potential link are falsifiable. First, organizational social capital is a collective resource that occurs at the group and organizational level, while commitment and engagement characterize the relationship of the employee to his or her organization, thus occurring at the individual level. Second, high levels of social capital may not always be aligned with high levels of engagement and commitment. For example, social capital can display negative organizational effects if it leads to the creation of in- and out-groups, suppresses the benefits of group diversity, or makes it more difficult for new organization members to join existing networks (e.g., Kroll \& Tantardini, 2019; Morrow, 1999). 
Here, we define both of our outcomes variables in more detail. Work engagement is a "persistent, positive affective-motivational state of fulfilment" (Maslach, Schaufeli, \& Leiter, 2001, p. 417). Engagement is about feeling good at work and feeling charged with energy, as opposed to being burned out. Organizational commitment is the sum of affective-emotional attachment to the organizations, the awareness of the costs of leaving the organization, and the normative obligation to continue employment (Meyer \& Allen, 1991). Although both concepts at least partially overlap (feeling good at work may increase commitment and vice versa), they are still conceptually and empirically distinguishable from each other, as illustrated by the fact that one can feel committed to an organization without being energized and vice versa (Hallberg \& Schaufeli, 2006).

\section{Theoretical Model}

When theorizing about the impact of organizational social capital on individuals, we need to keep in mind that there is no one, entirely agreed upon, account of the quantity or quality of social capital in an organization. Rather, the extent to which collaboration, trust, and shared values are perceived to be present may vary across teams and ultimately individuals. Hence, it is the individual perception of organizational social capital that may explain differences in employee-level attitudes and behaviors. This is consistent with assumptions made in research about organizational climate or culture, where the perceptions by individuals, which are likely to vary within organizations, are often the unit of analysis (James, 1982; Moynihan \& Pandey, 2006)

We argue that individual perceptions of organizational social capital are a function of the perceptions of the people surrounding the individual. To make this point, we draw on the extant 
literatures on team mental models (Rentsch \& Klimoski, 2001), transactive memory (Lewis, 2003), group learning (Wong, 2004), and strategic consensus (Knight et al., 1999). What these literatures have in common is the assumption that members of the same team tend to develop shared cognition about work tasks, team work processes, the environment the team operates in, as well as priorities and beliefs. While the observation that members of the same team are likely to share the same mental models seems to hold across contexts, there is variation in the development of team cognitions, which - if widely shared and mostly accurate - can yield positive performance effects (Mohammed et al., 2010).

Team members are likely to share mental models if teams are small, members had similar life experiences, and they were actively recruited to be on the team (Rentsch \& Klimoski, 2001). Other factors that foster the development of team mental models include autonomy, functional communication, and members' agreement about each other's expertise (Lewis, 2003) as well as cross-training (Marks, Sabella, Burke, \& Zaccaro, 2002). We know that stress diminishes teams' ability to collectively encode, store, and retrieve information, which in turn may negatively affect team performance (Ellis, 2006). Group diversity makes the creation of shared cognition and understanding less likely (Knight et al., 1999). At the same time, in very cohesive groups members' views and experiences may be so similar that actual learning is more likely to occur outside of the group (Wong, 2004). Group think theory (Janis, 1982) makes a similar point in that groups sharing the same mental models, decision heuristics, and biases are also more prone to ignoring group-external cues and insights, often due to pressure for consensus and conformity.

Overall, we find a great deal of support for Rentsch's (1990) seminal observation that the more employees interact with each other in groups, the more likely it becomes that they attach the same meaning to organizational events. Similarly, Willems (2016) finds that the quality of 
the exchanges among leadership teams in nonprofit organizations determines the convergence of their mental models. We adapt these observations to the case of organizational social capital and argue that individual perceptions of social capital are not developed in isolation. Rather, such perceptions are likely to be influenced by the perceptions of peers surrounding the individual. That is, the degree to which an employee perceives social capital to be present is a function of her own experiences but also the experiences shared by her immediate peers. In a group setting, individual perceptions of social capital will be adjusted according to average team perceptions. For example, after learning of negative team perceptions about organization-wide collaboration, trust or value congruence, an individual's sense of organizational social capital could be diminished. Conversely, team perceptions of high organizational social capital may positively influence individual perceptions of collaboration, trust, and value congruence across the entire organization.

$H_{1}$ : Team perceptions of organizational social capital shape individual perceptions of social capital.

The second part of our argument is that individual perceptions of organizational social capital explain differences in work-related attitudes such as engagement and commitment. We argue that organizational social capital has an impact on employees through three pathways - the creation collaborative relationships, trust, and the collective understanding of mission. This is in line with previous work showing that increases in organizational social capital over time in a panel of federal government agencies have a positive effect on employees' intrinsic motivation and a negative effect on turnover intention (Kroll \& Tantardini, 2019). 
Structural social capital, found in the collaborative relationships between employees, is expected to foster positive attachment to the job by facilitating communication and creating opportunities to get to know similar others. Structural social capital allows individuals to tap into collective resources, making it easier for the member to succeed in their organizational role (Andrews, 2010, 2011; Nahapiet \& Ghoshal, 1998). Kim and Rhee (2010) find that social networks foster organizational commitment, particularly if such networks are sizable and diverse, and network partners powerful. Research also shows that proactive employees who exploit the benefits of social networks are more engaged and successful (Bakker, Tims, \& Derks, 2012; Thompson, 2005).

The relational dimension of social capital is also expected to foster an employee's positive attachment to their job. Conceptualized in previous literature as trust, relational social capital reduces the transaction costs of social interactions, fostering information sharing and horizontal learning in the process (Adler \& Kwon, 2002; Nahapiet \& Ghoshal, 1998). Trust is also a condition for building a sense of togetherness. Work by Chughtai and Buckley (2013) suggests that trust in managers and team members affects work engagement through the creation of identification and psychological safety. Similarly, a study set up in the public sector finds that interpersonal trust fosters affective organizational commitment, pointing to the importance of bottom-up trust building initiatives (Nyhan, 1999).

The cognitive dimension of social capital, in the collective understandings of mission, is expected to strengthen an employee's attachment to their job (Leana \& Van Buren III, 1999; Holme \& Rangel, 2012). Employees are expected to be more engaged if they can link their tasks to the overall purpose of the organization and its higher-order objectives (Erikson, 1986; Hummel, 1994). Along these lines, Shteynberg and Galinsky (2011, p. 1291) find that "sharing 
goals with similar others intensifies goal pursuit" and in a meta-analysis, Kristof-Brown et al. (2005) show that person-organization fit is strongly correlated with organizational commitment. $\mathrm{H}_{2}$ : Individual's perceptions of organizational social capital (structural, relational, and cognitive) are positively associated with their work engagement and organizational commitment.

\section{Data and Method}

\section{Sample}

The data we use to test our hypotheses were collected in 2016 by a survey questionnaire administered to the employees of 1) a city in a metropolitan area and 2) an urban city's department of social services in North Carolina. The organizations were the tenth and eleventh participants in the Local Government Workplaces Initiative, a cross-organizational data collection started in 2004 to study organizational dynamics in cities and counties. We only use data from those two organizations for which the survey instrument included all questions that were relevant for our research project.

The city and the county social services department participating in this study self-selected into data collection in order to better understand the perspectives of their employees on a range of workplace issues. In the United States, cities provide basic functions to residents within its jurisdiction: public safety, including fire and police services; public works, which encompasses street maintenance, water delivery, and trash collection; parks and recreation; and libraries. From a workforce perspective, local governments hire both blue and white collar workers, with 
employees diverse in education (from the GED to the $\mathrm{PhD}$ ) and skill sets (accountants, lawyers, engineers, trades, law enforcement, and public administrators). Departments of social services, which reside within county organizations, assist in the delivery of financial assistance and programs in support of vulnerable community members, including families, the elderly, and disabled adults. Social service professionals tend to have associates, bachelors, or master's degrees in social work.

The research team sought the perspectives of employees throughout each organization's hierarchy, representing an "echelon" approach of multiple informants with different organizational perspectives (Walker \& Brewer, 2008) Accordingly, questionnaires were distributed to all full-time regular employees of both organizations, totaling 1,710 employees. Individuals are nested within departments and teams. Departments are the first grouping level, and teams constitute the next hierarchical grouping level within each department.

The survey process was implemented using the principles of the Tailored Design Method, featuring multiple contacts and consistent messaging with prospective research participants (Dillman, Smyth, \& Christian, 2014). Each survey process began with an email from the top organizational leader to employees work emails expressing support for the study, encouraging voluntary participation, guaranteeing confidentiality, and allowing the survey to be completed during work hours. Within two weeks of the alert email, survey invitations were emailed to employee work emails with a personalized Qualtrics link. Survey invitations stressed the voluntary and confidential nature of survey participation. In the city studied, employees without ready access to a computer were given access to conveniently located computer labs, with research team members available to assist employees in navigating Qualtrics. This process yielded 1,452 usable responses, representing a sample-weighted response rate of $82 \%$ ( $85 \%$ for 
the town and $73 \%$ for the social service department). Both samples represent the population of employees in the distribution of departments, age, gender, race and ethnicity, and managerial status. $^{2}$

\section{Measures}

The exact wording of all our measures and their reliability scores can be found in the appendix. The first dependent variable - work engagement - is operationalized by four items adapted from the Utrecht work engagement scale (Schaufeli \& Bakker, 2003) (e.g. "When I get up in the morning, I look forward to going to work"). The items have been slightly adjusted to reflect the specific nature of the local government work context. Organizational commitment the second dependent variable - was measured using four items (e.g. "I would feel guilty if I left this organization now") developed by Meyer, Allen, and Smith (1993). Two of the commitment items reflect affective commitment and two reflect normative commitment.

We operationalized organizational social capital (OSC) as a second-order factor consisting of three first-order factors. These first-order factors reflect the three dimensions structural, relational, and cognitive organizational social capital. Each dimension is measured using two to three items. For example, participants scored items like "employees in my department function as a team" (structural OSC) or "employees trust supervisors to do the right thing on their behalf" (relational OSC). The item formulation followed a referent-shift consensus model (Chan, 1998), which means that the items are formulated in a way addressing respondents' perception of their organization as a whole instead of their individual social capital. Hence, reference points for the items are not the individual-level ("I trust my supervisor") but the

\footnotetext{
2 The local government organizations studied are not unionized, nor do they feature employee associations that formally facilitate employee voice.
} 
group-level ("Employees trust their supervisor") (van Mierlo, Vermunt, \& Rutte, 2008). The confirmatory factor analysis reveals a good fit of the second-order factor structure $\left(\chi^{2}(17)=86.2\right.$, $\mathrm{p}<.001 ; \mathrm{CFI}=.97 ; \mathrm{TLI}=.95 ; \mathrm{RMSEA}=.056 ; \mathrm{SRMR}=.036)$ and all paths in the model are significant $(\mathrm{p}<.01)$, with factor loadings ranging between .66 and .89 (see figure 1). ${ }^{3}$ This second-order model with three first-order factors fits the data considerably better than a single factor model $\left(\chi^{2}(20)=748.6, \mathrm{p}<.001, \mathrm{CFI}=.68, \mathrm{TLI}=0.56, \mathrm{RMSEA}=.167, \mathrm{SRMR}=.128\right)$.

We construct individual and team perceptions of OSC using Kenny, Mannetti, Pierro, Livi, and Kashy's (2002) actor-partner interdependence model (APIM). APIM was developed in research on couples that was interested in how the attitudes or behaviors of one partner affect those of the other partner. Hence, effects on outcome variables like life satisfaction are a function of the variance between couples, within couples, or both (Kashy \& Snyder, 1995). Kenny et al. (2002) adopted this approach to the research on small groups and similarly argued that statistical effects can result from team members' individual attitudes and behaviors, other team members' attitudes and behaviors, or a combination of both.

While individual OSC and team OSC are created at different levels (individual versus team) based on data from different informants, they both draw on the responses to the same set of OSC items listed in the appendix. However, both measures are distinct in that individual OSC perceptions are based on one employee's responses, while team OSC perceptions are based on the averaged responses by that employee's colleagues. For example, consider team members A, B, C, and D. For employee A, this person's OSC responses make up her individual OSC score, while the average of the responses by employees B, C, and D constitute the team OSC score. For

\footnotetext{
${ }^{3}$ It is noteworthy that there is no one widely adopted and validated measurement scale of organizational social capital. However, when developing our items we followed other precedents and suggestions made by previous research, including Andrews (2010); (2011), Tantardini and Kroll (2015), and Alexander and Ruderman (1987).
} 
employee B, this person's OSC responses make up his individual OSC score, while the average of the responses by employees A, C, and D constitute the team OSC score, and so forth. ${ }^{4}$

Figure 1: Confirmatory factor analysis of organizational social capital

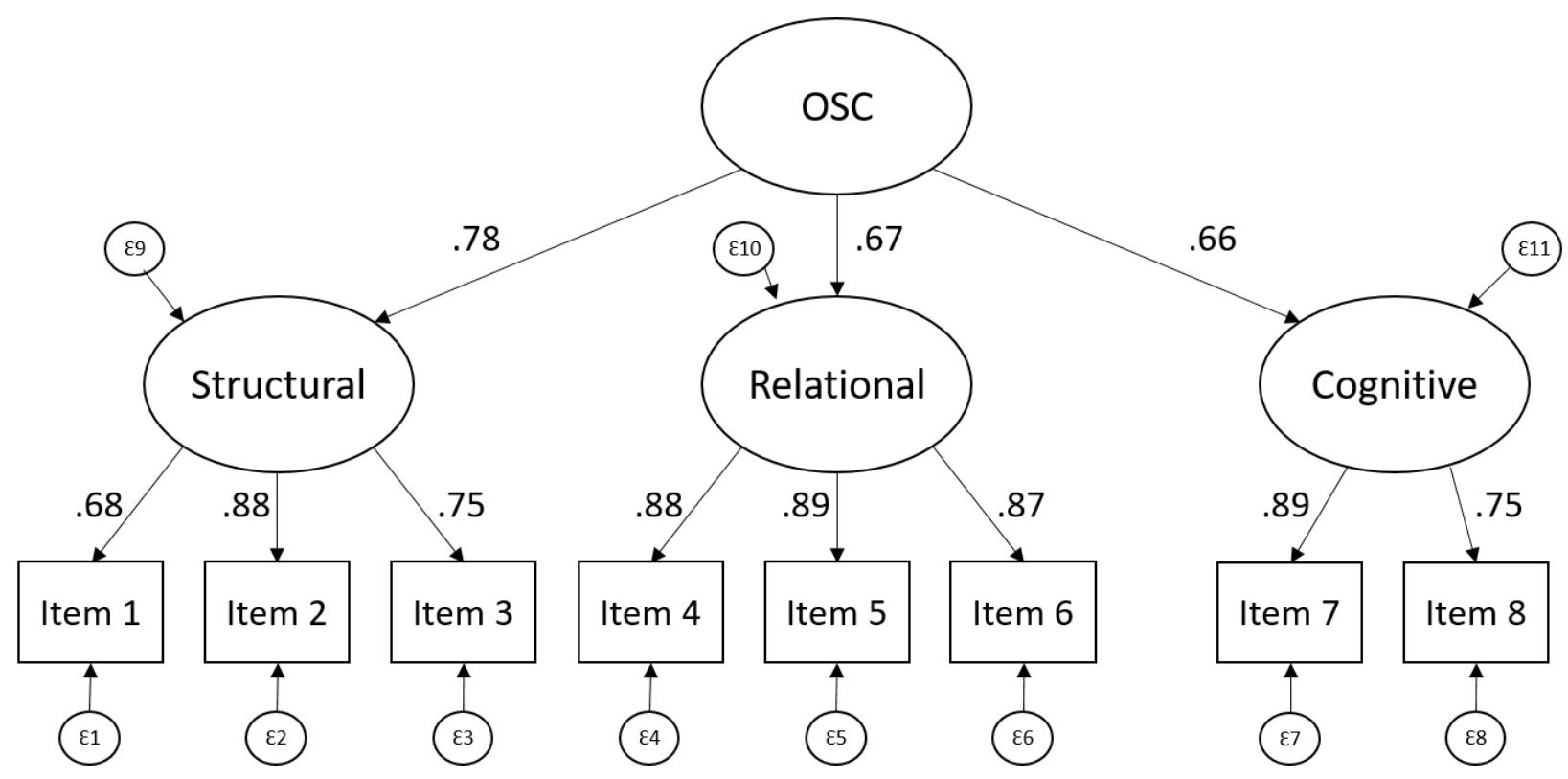

Note: OSC = organizational social capital. Standardized factor loadings are displayed.

Estimation method: Maximum likelihood estimation with clustered standard errors.

In order to minimize omitted variable bias, we included control variables at the individual and organizational levels, which are all listed in the appendix. Like previous research on engagement and commitment, we include demographic variables (education, gender, age, race, and tenure) as well as some context factors (team size, organization) in our models (Loi, Hang-

${ }^{4} M^{\prime}{ }_{X}=\left(n M_{X}-X_{i}\right) /(n-1)$ Where $\mathrm{n}$ is the number of responses in a team, $M^{\prime}{ }_{X}$ is the other team members' OSC, $n$ is the number of team members, $M_{X}$ is the mean of all team members, and $\mathrm{X}_{\mathrm{i}}$ is the OSC of individual $i$. 
Yue, \& Foley, 2006; Raub \& Blunschi, 2014). At the same time, we want to account for organizational and job-related variables that could serve as alternative predictors of engagement and commitment. We think that - relatively independent of an organizations' social capital employees tend to be more engaged and committed when they experience procedural fairness in the workplace (Loi et al., 2006; Strom, Sears, \& Kelly, 2014). We further want to disentangle social capital effects from just a general feeling of satisfaction with the work environment, which is why we also control for the latter variable (Caykoylu, Egri, Havlovic, \& Bradley, 2011). In line with job demands-resources theory, we expect employees to show more positive work attitudes if they are being given autonomy (Crawford, LePine, \& Rich, 2010). Lastly, purpose, or more specifically job significance, is another important positive driver of engagement and commitment, which we will account for in our models (Raub \& Blunschi, 2014).

Table 1: Descriptive statistics

\begin{tabular}{lcccc}
\hline & Mean & S.D. & $\min$ & $\max$ \\
\hline Engagement & -0.02 & 1.00 & -2.80 & 1.23 \\
Commitment & -0.01 & 1.00 & -2.39 & 1.60 \\
Indi. OSC & -0.01 & 0.78 & -3.25 & 1.31 \\
Partner OSC & 0.00 & 0.34 & -1.87 & 1.31 \\
Procedural Fairness & 0.00 & 1.00 & -1.39 & 2.83 \\
Autonomy & -0.01 & 1.00 & -3.45 & 1.67 \\
Satisfaction working envir. & 0.00 & 0.99 & -3.69 & 1.44 \\
Job Significance & 0.01 & 0.96 & -4.27 & 0.83 \\
Education & 1.92 & 1.21 & 0.00 & 4.00 \\
Age & 43.61 & 10.97 & 17.00 & 81.00 \\
White & 0.72 & 0.45 & 0.00 & 1.00 \\
Tenure & 9.13 & 7.62 & 0.00 & 37.00 \\
Gender $(1=$ female) & 0.43 & 0.50 & 0.00 & 1.00 \\
Team Size & 20.75 & 32.96 & 2.00 & 192.00 \\
\hline
\end{tabular}


Table 2: Correlations

\begin{tabular}{|c|c|c|c|c|c|c|c|c|c|c|c|c|}
\hline Individual level & (1) & (2) & (3) & (4) & $(5)$ & (6) & (7) & $(8)$ & (9) & $(10)$ & $(11)$ & $(12)$ \\
\hline (3) Individual OSC & $0.57^{*}$ & $0.58^{*}$ & 1.00 & & & & & & & & & \\
\hline (5) Procedural fairness & $0.38^{*}$ & $0.38^{*}$ & $0.42^{*}$ & $0.14^{*}$ & 1.00 & & & & & & & \\
\hline (6) Autonomy & $0.37^{*}$ & $0.31^{*}$ & $0.38^{*}$ & $0.08^{*}$ & $0.43^{*}$ & 1.00 & & & & & & \\
\hline (7) Satisf. work envir. & $0.55^{*}$ & $0.54^{*}$ & $0.60^{*}$ & $0.12^{*}$ & $0.42^{*}$ & $0.42^{*}$ & 1.00 & & & & & \\
\hline (10) Age & $0.14^{*}$ & $0.08^{*}$ & $0.07^{*}$ & 0.01 & $0.13^{*}$ & $0.16^{*}$ & $0.06^{*}$ & 0.03 & 0.02 & 1.00 & & \\
\hline (11) White & $0.13^{*}$ & $0.13^{*}$ & $0.18^{*}$ & $0.31^{*}$ & $0.12^{*}$ & $0.09^{*}$ & 0.02 & $-0.10^{*}$ & $-0.20^{*}$ & 0.02 & 1.00 & \\
\hline (12) Tenure & 0.03 & 0.03 & -0.01 & 0.01 & $0.07^{*}$ & $0.06^{*}$ & -0.00 & $0.06^{*}$ & $-0.17^{*}$ & $0.42^{*}$ & $0.09^{*}$ & 1.00 \\
\hline (13) Gender & $-0.11^{*}$ & -0.04 & $-0.08^{*}$ & $-0.14^{*}$ & $-0.08^{*}$ & 0.04 & -0.02 & -0.04 & $0.24^{*}$ & $0.09^{*}$ & $-0.41^{*}$ & $-0.10^{*}$ \\
\hline
\end{tabular}


All constructs measured by more than two items have been operationalized as standardized factors using principal component analyses with PROMAX rotation. Table 1 gives an overview of the descriptives of the variables. The sample is 43 percent female and 28 percent employees of color. The average respondent is 44 years of age and has been employed by the organization for nine years. The average team size is 21 members. Table 2 shows all intervariable correlations.

The dependent variables are correlated with $r=.69$ (they share $48 \%$ of variation) indicating that they are related but not identical and that it is worth studying them separately. The dependent variables are correlated with Individual OSC at levels of $r=.57 / .58$ and with team OSC at $r=.25 / .20$. All correlations are modest (the highest correlation being .60), suggesting that none of the independent or control variables are correlated too highly to distort the regression models.

\section{Analytical procedure}

In order to test our hypotheses, we used a hierarchical linear model for each of the two dependent variables. The models allow for varying intercepts for each team (random intercept model) and account for the clustered structure of the data. We also tested if varying slopes could improve the models but did not find any improvement. Therefore, we decided to use the most parsimonious model by fixing the slopes at team-level and estimating a random intercepts model only. The model can be formalized the following way: 


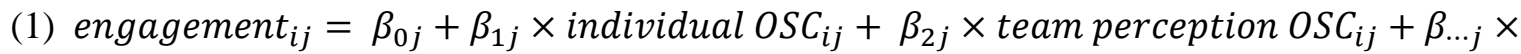
[individual level controls $\left.s_{i j}\right]+e_{i j}$

(2) $\beta_{0 j}=\gamma_{00}+\gamma_{01} \times$ Organization $_{j}+\gamma_{02} \times$ team size $_{j}+u_{0 j}$

$$
\begin{aligned}
& \beta_{1 j}=\gamma_{10} \\
& \beta_{2 j}=\gamma_{20} \\
& \beta_{\cdots j}=\gamma_{\cdots 0}
\end{aligned}
$$

To test the proposed indirect effect, we employ a set of regressions rather than structural equation modelling. While the latter has its advantage in providing several global fit indices, it is badly suited to handle larger numbers of control variables. Since our focus is on exploiting the multilevel structure of the data and accounting for a good number of relevant confounding factors at the individual and team level, we opt for the use of several hierarchical linear regression models rather than one structural equation model.

To examine the indirect effect of $X$ on $Y$ through the intervening variable $I V$, we run two regressions: First, $I V$ is regressed on $X$ to establish the link between the independent variable and the intervening variable. Second, $Y$ is regressed on $X$ and $I V$ to separate the effect of the independent variable from that of the intervening variable on the dependent variable. Since we examine two dependent variables, we offer two tests of each regression equation. We expect that 1) $X$ is related to $I V, 2) I V$ is related to $Y$, and 3) there is no significant direct effect of $X$ on $Y$ once the impact of $I V$ is accounted for. We make no assumptions about the existence of a total effect between $X$ and $Y$, which is why our modeling approach is in line with the recommendations by Hayes (2009) and Zhao, Lynch, and Chen (2010) and slightly different from Baron and Kenny (1986). 


\section{Results}

Figure 2 shows a summary of our results for the proposed indirect effect, separated by dependent variable. For the sake of brevity, the figure only incorporates the variables we theorized about in our hypotheses, whereas the findings for the eleven control variables are omitted (but they are reported in table 3). Figure 2 shows that team perceptions of organizational social capital have a significant impact on employees' engagement and commitment because they shape the individual's experience of social capital in a first step. The path coefficients are substantive and significant, and we find it noteworthy that the indirect effects are significant $(b=$ $0.14, p<0.01 ; b=0.17 ; p<0.01 ; p$-values are bootstrapped), while the direct effect is not. This is evidence in favor of our two hypotheses.

In addition to the presentation of our main findings, we now review the findings for our control variables, the appropriateness of the use of hierarchal linear modeling, and the performance of our models. 
Figure 2: Summary of findings for proposed indirect effect

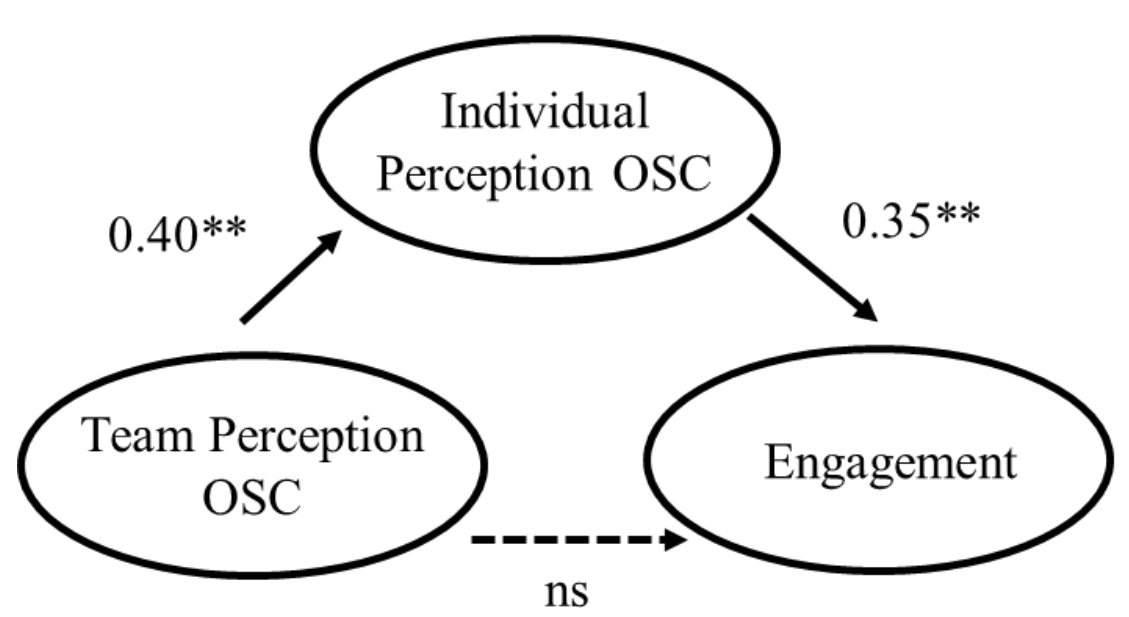

Indirect effect: $\mathrm{p}<.01$

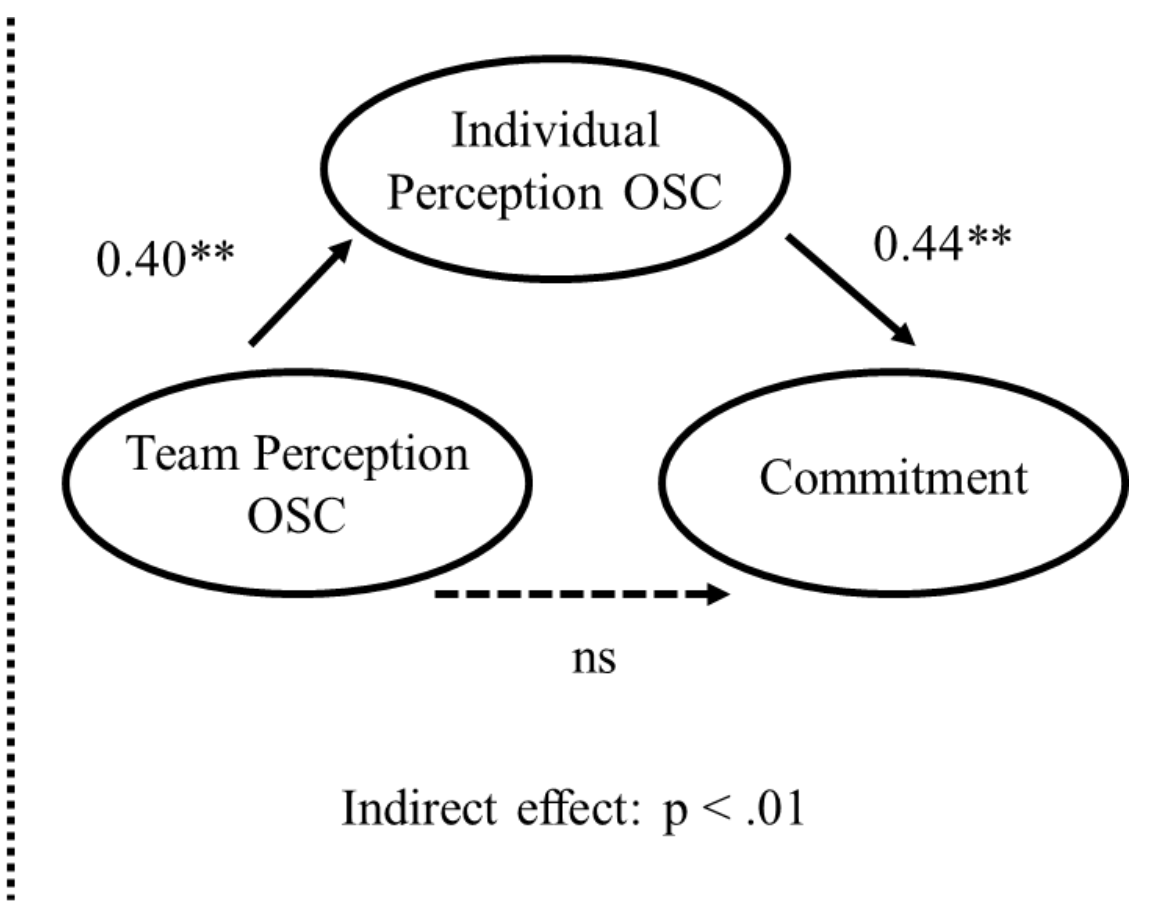

Notes: ** $\mathrm{p}<0.01 ; \mathrm{ns}=$ not significant; hierarchical linear models; all regressions control for the following variables: Procedural fairness, Satisfaction work environment, Autonomy, Job significance, Education, Gender, Age, Race, Tenure (all individual level), Organization, Team size (both team level); $\mathrm{n}($ employees $)=1,191-1,193 ; \mathrm{n}$ (teams) $=63$; the full set of results can be found in table 3 , see models 1,3 , and 5 . 
Focusing on the control variables, we can see a few significant effects. Three of them have an impact on work engagement as well as organizational commitment. The fairer employees perceives the procedures in their department, the more work engagement and organizational commitment they report. This is line with the findings from other research showing that procedural justice is an important antecedent of work engagement (Saks, 2006; Strom et al., 2014) and organizational commitment (Loi et al., 2006; Lowe \& Vodanovich, 1995). In addition, satisfaction with the work environment also increases engagement and commitment. A bit surprisingly, the more educated respondent are, the lower are their levels of work engagement and organizational commitment. As previous research concludes, this might be the result of higher expectations by those with more education with respect to their organizations (Mathieu \& Zajac, 1990; Mowday, Koberg, \& McArthur, 1984).

Some additional control variables show an effect only on one of the dependent variables. The more autonomous and the older an employee, the more he or she is engaged. In contrast, many years of employment in a single organization reduces respondents' work engagement; a finding that is consistent with previous results on demotivational tendencies that long-time employees in the public sector display (e.g. Vogel \& Kroll, 2016). With respect to organizational commitment, female employees and those who see the significance of their daily work show higher values. 
Table 3: Full set of hierarchical linear models

\begin{tabular}{|c|c|c|c|c|c|}
\hline & $\begin{array}{c}(1) \\
\text { Individual OSC }\end{array}$ & $\begin{array}{c}\text { (2) } \\
\text { Engagement }\end{array}$ & $\begin{array}{c}\text { (3) } \\
\text { Engagement }\end{array}$ & $\begin{array}{c}(4) \\
\text { Commitment }\end{array}$ & $\begin{array}{c}\text { (5) } \\
\text { Commitment }\end{array}$ \\
\hline $\begin{array}{l}\text { Individual level } \\
\text { Individual perception } \\
\text { OSC }\end{array}$ & & & $\begin{array}{l}0.35^{* *} \\
(9.08)\end{array}$ & & $\begin{array}{c}0.44^{* * *} \\
(11.15)\end{array}$ \\
\hline $\begin{array}{l}\text { Team perception } \\
\text { OSC }\end{array}$ & $\begin{array}{l}0.40^{* *} \\
(6.69)\end{array}$ & & $\begin{array}{c}0.12 \\
(1.47)\end{array}$ & & $\begin{array}{c}-0.04 \\
(-0.43)\end{array}$ \\
\hline Procedural fairness & $\begin{array}{l}0.12^{* * *} \\
(6.02)\end{array}$ & & $\begin{array}{l}0.08^{* *} \\
(2.86)\end{array}$ & & $\begin{array}{l}0.12^{* *} \\
(4.46)\end{array}$ \\
\hline $\begin{array}{l}\text { Satisfaction work } \\
\text { environment }\end{array}$ & $\begin{array}{c}0.32^{* *} \\
(16.12)\end{array}$ & & $\begin{array}{l}0.28^{* *} \\
(9.63)\end{array}$ & & $\begin{array}{l}0.26^{* *} \\
(8.67)\end{array}$ \\
\hline Autonomy & $\begin{array}{l}0.10^{* *} \\
(4.82)\end{array}$ & & $\begin{array}{l}0.11^{* *} \\
(4.11)\end{array}$ & & $\begin{array}{c}0.01 \\
(0.48)\end{array}$ \\
\hline Job significance & $\begin{array}{l}0.11^{* *} \\
(5.73)\end{array}$ & & $\begin{array}{c}0.02 \\
(0.80)\end{array}$ & & $\begin{array}{l}0.05^{*} \\
(2.06)\end{array}$ \\
\hline Education & $\begin{array}{c}0.02 \\
(1.11)\end{array}$ & & $\begin{array}{l}-0.08^{* *} \\
(-4.14)\end{array}$ & & $\begin{array}{l}-0.08^{* *} \\
(-3.96)\end{array}$ \\
\hline $\begin{array}{l}\text { Gender } \\
(1=\text { female })\end{array}$ & $\begin{array}{c}0.05 \\
(1.24)\end{array}$ & & $\begin{array}{l}-0.06 \\
(-1.12)\end{array}$ & & $\begin{array}{l}0.15^{* *} \\
(2.59)\end{array}$ \\
\hline Age & $\begin{array}{c}0.00 \\
(1.84)\end{array}$ & & $\begin{array}{l}0.01^{* *} \\
(4.66)\end{array}$ & & $\begin{array}{c}0.00 \\
(0.94)\end{array}$ \\
\hline Race $(1=$ white $)$ & $\begin{array}{l}0.14^{* *} \\
(2.67)\end{array}$ & & $\begin{array}{l}-0.07 \\
(-0.97)\end{array}$ & & $\begin{array}{c}0.01 \\
(0.18)\end{array}$ \\
\hline Tenure & $\begin{array}{l}-0.01^{* *} \\
(-2.80)\end{array}$ & & $\begin{array}{c}-0.01^{*} \\
(-2.14)\end{array}$ & & $\begin{array}{c}-0.00 \\
(-0.22)\end{array}$ \\
\hline $\begin{array}{l}\text { Team level } \\
\text { Organization }\end{array}$ & $\begin{array}{c}-0.06 \\
(-0.85)\end{array}$ & & $\begin{array}{c}-0.10 \\
(-1.05)\end{array}$ & & $\begin{array}{l}-0.18^{*} \\
(-2.03)\end{array}$ \\
\hline Team size & $\begin{array}{c}0.00^{*} \\
(2.17)\end{array}$ & & $\begin{array}{c}0.00 \\
(1.63)\end{array}$ & & $\begin{array}{c}0.00 \\
(0.70)\end{array}$ \\
\hline Constant & $\begin{array}{l}-0.29^{* *} \\
(-3.00) \\
\end{array}$ & $\begin{array}{r}-0.07 \\
(-1.31) \\
\end{array}$ & $\begin{array}{r}-0.24 \\
(-1.82) \\
\end{array}$ & $\begin{array}{c}-0.04 \\
(-0.76)\end{array}$ & $\begin{array}{c}0.00 \\
(0.01)\end{array}$ \\
\hline Var. level 2 residuals & $\begin{array}{l}0.00^{* *} \\
(-7.16)\end{array}$ & $\begin{array}{l}0.10^{* *} \\
(-7.13)\end{array}$ & $\begin{array}{l}0.01^{* *} \\
(-5.74)\end{array}$ & $\begin{array}{l}0.06^{* *} \\
(-7.19)\end{array}$ & $\begin{array}{l}0.01^{* *} \\
(-3.08)\end{array}$ \\
\hline Var. level 1 residuals & $0.31^{* *}$ & $0.91^{*}$ & $0.55^{* *}$ & 0.94 & $0.57^{* * *}$ \\
\hline
\end{tabular}




\begin{tabular}{lc|cc|cc} 
& $(-28.21)$ & $(-2.36)$ & $(-14.20)$ & $(-1.38)$ & $(-13.13)$ \\
\hline $\mathrm{n}$ (followers) & 1193 & 1192 & 1192 & 1191 & 1191 \\
$\mathrm{n}$ (teams) & 63 & 63 & 63 & 63 & 63 \\
$\mathrm{R}^{2}$ (S\&B) & 0.50 & & 0.56 & & 0.58 \\
$\mathrm{AIC}$ & 2035.20 & 3328.96 & 2722.01 & 3357.36 & 2756.11 \\
$\mathrm{BIC}$ & 2111.47 & 3344.21 & 2803.34 & 3372.60 & 2837.43 \\
$\log$ likelihood & -1002.60 & -1661.48 & -1345.00 & -1675.68 & -1362.05 \\
\hline
\end{tabular}

Note: Hierarchical linear models. Estimator: maximum likelihood; t-values in parentheses; ${ }^{*} \mathrm{p}<0.05, * * \mathrm{p}<0.01$

For our analysis, we use multilevel modelling, which is the most appropriate estimation strategy given the structure of our data. The ICC(1) of the dependent variables is 0.09 (work engagement) and 0.07 (organizational commitment), indicating that $9 \%$ of an individual's work engagement can be explained by team membership (Bliese, 2000). The ICC(2) for the two variables is 0.67 and 0.54 , indicating a modest reliability of the group mean (Woehr, Loignon, Schmidt, Loughry, \& Ohland, 2015). Although, the ICC(1) is relatively low, neglecting the clustering of the data could result in severely biased estimators. We also tested the interrater agreement for the OSC measures following Bliese's (2016) suggestions. The results show that the three factors of OSC, structural $\left(r_{w g(j)}=.71 ; A D=1.00\right)$, relational $\left(r_{w g(j)}=.64 ; A D=1.22\right)$, and cognitive $\left(r_{w g(j)}=.71 ; A D=1.21\right)$ OSC show good agreement and are all—as advisedabove $\left(r_{w g(j)}\right)$ or below $(A D)$ simulated significance thresholds. ${ }^{5}$ Based on this information, it is appropriate to use hierarchical linear models to test our hypotheses and to aggregate team members' perception of OSC to the team level.

In addition to conducting our main analysis, we use table 3 to examine how our fully fitted regressions perform and compare them against the null model (models 2 versus 3 and models 4 versus 5). First, we turn to the model fit of the full models (model 3 and 5). We used

\footnotetext{
${ }^{5}$ The simulated significance thresholds are $r_{w g(j)}=.45$ and $A D=1.42$ for structural OSC, $r_{w g(j)}=.52$ and $A D=1.39$ for relational, as well as $r_{w g(j)}=.43$ and $A D=1.78$ for cognitive.
} 
Snijders and Bosker (1994) $R^{2}(S \& B)$ to address the explained variance of the models. $R^{2}(S \& B)$ indicates how much variance a model explains in comparison to the respected null model that uses group membership as the only predictor (LaHuis, Hartman, Hakoyama, \& Clark, 2014). The values indicate that our models reduce the amount of unexplained variance by $56 \%$ (work engagement) and $58 \%$ (organizational commitment). The Akaike Information Criterion (AIC) and the Bayesian Information Criterion (BIC) also indicate a good model fit. All four values of the final models are lower than the values of the corresponding null model. For work engagement, AIC declines from 3329 to 2722 and BIC from 3344 to 2803 . For organizational commitment the AIC drops from 3357 to 2756 and the BIC from 3373 to 2837. Finally, the log likelihood test is significant for both models. Overall, we can conclude that our models perform well.

\section{Discussion}

Our findings add to the literature on social capital of firms (Chow \& Chan, 2008; Clercq et al., 2013; Sherif et al., 2006) and public organizations (Andrews, 2010; Compton \& Meier, 2016; Holme \& Rangel, 2012). While previous work has established the link between social capital and organizational performance by examining organization-wide aggregate scores, little was known about the mechanisms at the micro level of the organization, which link the two variables. We show evidence for such a link through the impact on employees' engagement and commitment and provide evidence for the important role of teams in shaping individuals' perceptions of organizational social capital.

We find evidence for the relationship between individually perceived social capital with organizational commitment and work engagement. Put simply, when employees perceive 
collaboration, trust and an understood and achieved mission, they are more likely to be engaged and committed to the organization. Given that work engagement and organizational commitment have been linked with various measures of organizational performance, this finding provides some new theoretical routes from social capital to performance.

Our second finding is an important qualification of the first one. While individual perceptions of social capital are crucial, they are not formed in isolation. Rather, individual perceptions are largely shaped by the peers surrounding the individual (Mohammed et al., 2010; Rentsch, 1990). Our findings imply the importance of the team in fostering a collective a sense of organizational social capital that translates to individual outcomes. This suggests that those organizations seeking to strengthen their psychological assets should focus specifically on building collaboration, trust and a sense of mission among teams as well as to individual employees. This recommendation is particularly instructive for organizational development efforts that target employees writ large, but leave team development up to team leaders. In these circumstances, public organizations are missing an important opportunity to harness team perceptions of organizational capital in service of motivating individual employees.

We see ample opportunities for future research. We consider the support for the indirect effect of team perceptions of social capital on positive individual-level work attitudes largely robust (particularly since our findings hold for commitment and engagement). At the same time, we also acknowledge the need to identify important contingency factors. For example, team cognition may be less influential in cases in which individuals have as much or even more exposure to members from other teams. Alternatively, the role of the team may decrease as the number of out-group members increases. That is, if team members feel less a sense of belonging to their teams, they will be less likely to listen to the views, narratives, and experiences of team 
members. Lastly, team homogeneity may enhance team effects because individuals may be more likely to buy into team cognition, the more similar they are to other team members. This idea is informed by work showing that social capital has a complicated relationship with diversity. Along these lines, we also recognize that organizational social capital is a positive normative concept only in settings that seek to preserve democracy and achieve the realization of public values, while in other settings organizational social capital could easily produce administrative evil.

We acknowledge limitations of our research that readers should keep in mind when drawing inferences from our findings. We draw all our data from two local government organizations, which may raise the issue of generalizability, but it also makes the test of our theory conservative. If perceptions of social capital vary and are influential, despite the fact that all of them were collected from the same two organizations, we can expect more variation and even stronger effects if our theory is tested using a much more diverse sample of organizations. However, to increase potential variation in perceptions, our organizational social capital questions refer to the level of departments within each organization. Another factor strengthening the generalizability of our results is that local governments are functionally diverse entities, providing services that range from public safety to arts and culture to streets and sanitation. Similarly, local government employees are diverse, not only demographically (survey respondents in this sample were 42.9 percent female and 28.4 percent people of color) but also educationally: our respondents hold graduate (17.6 percent) and undergraduate degrees (42.5 percent), as well as GEDs (9.74 percent). The remaining employees have had some college or some graduate school. 
Common source bias may be a second concern, although we see four reasons why this should not jeopardize the validity of our study. First, our variables of interest are personal attitudes, and to the best of our knowledge, there is no better way to capture such attitudes than using self-reports. Second, we tap into different data sources to measure our main independent variable and the two dependent variables. While the latter were captured through individual selfreports, the former was constructed as a team-level variable, drawing the data from the individual's peers. Third, previous research found that measures mostly prone to bias were related to organizations' performance ratings. Hence, variables that carry less social desirability bias - such as social capital - may also be less susceptible to common method variance. Fourth, and in line with what George and Pandey (2017) argue, the threat that a common method poses may have been overstated in recent public administration scholarship. Although such bias can affect the statistical results, it is often unclear whether this favors the null or research hypothesis, and whether bias ever reaches a substantive impact.

\section{Conclusion}

In this article, we have examined the micro-level mechanisms of social capital in organizations. In particular, we have studied how perceptions of organization-wide capital at different levels affect employee-level work attitudes. We have looked at effects on two such attitudes (engagement and commitment), thereby, providing two tests for each hypothesis. Drawing on an organizationally representative sample of nearly twelve hundred individuals from two local government organizations in North Carolina, we found the following: Individual perceptions of social capital are important determinants of both work engagement and 
organizational commitment. However, individual perceptions of social capital are shaped through social interactions with team members, suggesting that work groups constitute prisms through which employees view the entire organization, and that the effect on engagement and commitment is indirect.

Overall, the study points to the importance of teams in facilitating positive perceptions of organization-wide social capital, which have not received much attention in previous work. Teams diffuse mental models among members, and they are the primary experiential pathway between employee and the organization. Hence, interventions at the team level can be a promising route to facilitate organization-wide social capital and related positive effects. In particular, our results suggest that public managers should focus on developing collaboration, trust and a mission focus within teams. The literature on team effectiveness is instructive on this point (see Salas, Goodwin, \& Burke, 2008): team leaders can foster collaboration by encouraging team members to speak up and listen to each other (Edmondson \& Roloff, 2008); leaders can use transformational tactics (Özaralli, 2003), such as repeatedly talking about the meaningfulness of the work in team meetings; and leaders can facilitate team meetings by which members develop a shared vision of how group goals connect with organizational mission (Sundstrom, De Meuse, \& Futrell, 1990).

While we know a great deal about social capital effects at the macro level (organizations that own social capital tend to outperform others), little is known about how such gains are created and how this capital positively affects individuals. This article offers such a micro level perspective. It incorporates literature on teams and work groups and examines how teams and individuals interact, thereby adding to public administration scholarship that rarely looks at multiple organizational levels and potential interdependencies simultaneously. It also promises 
public managers - in an era of fiscal constraint and heightened service expectations - a more holistic framework for understanding workplace climate and language for articulating the emotional assets they can build in public organizations. 


\section{References}

Adler, P. S., \& Kwon, S.-W. (2002). Social Capital: Prospects for a new concept. Academy of Management Review, 27(1), 17-40. https://doi.org/10.5465/AMR.2002.5922314

Alexander, S., \& Ruderman, M. (1987). The role of procedural and distributive justice in organizational behavior. Social Justice Research, 1(2), 177-198. https://doi.org/10.1007/BF01048015

Andrews, R. (2010). Organizational social capital, structure and performance. Human Relations, 63(5), 583-608. https://doi.org/10.1177/0018726709342931

Andrews, R. (2011). Exploring the Impact of Community and Organizational Social Capital on Government Performance. Political Research Quarterly, 64(4), 938-949. https://doi.org/10.1177/1065912910381649

Bakker, A. B., Tims, M., \& Derks, D. (2012). Proactive personality and job performance: The role of job crafting and work engagement. Human Relations, 65(10), 1359-1378. https://doi.org/10.1177/0018726712453471

Balfour, D. L., \& Wechsler, B. (1996). Organizational Commitment: Antecedents and Outcomes in Public Organizations. Public Productivity \& Management Review, 19(3), 256-277. https://doi.org/10.2307/3380574

Baron, R. M., \& Kenny, D. A. (1986). The moderator-mediator variable distinction in social psychological research: Conceptual, strategic, and statistical considerations. Journal of Personality and Social Psychology, 51(6), 1173-1182. https://doi.org/10.1037/00223514.51.6.1173

Bliese, P. D. (2000). Within-Group Agreement, Non-Independence, and Reliability: Implications for Data Aggregation and Analysis. In K. J. Klein \& S. W. J. Kozlowski (Eds.), Frontiers of industrial and organizational psychology: Vol. 12. Multilevel theory, research, and methods in organizations: Foundations, extensions, and new directions (pp. 349-381). San Francisco: Jossey-Bass.

Bliese, P. D. (2016). Multilevel Modeling in R (2.6): A Brief Introduction to R, the multilevel package and the nlme package. Retrieved from https://cran.rproject.org/doc/contrib/Bliese_Multilevel.pdf

Caykoylu, S., Egri, C. P., Havlovic, S., \& Bradley, C. (2011). Key organizational commitment antecedents for nurses, paramedical professionals and non-clinical staff. Journal of Health Organization and Management, 25(1), 7-33. https://doi.org/10.1108/14777261111116806

Chan, D. (1998). Functional relations among constructs in the same content domain at different levels of analysis: A typology of composition models. Journal of Applied Psychology, 83(2), 234-246. https://doi.org/10.1037/0021-9010.83.2.234

Chow, W. S., \& Chan, L. (2008). Social network, social trust and shared goals in organizational knowledge sharing. Information \& Management, 45(7), 458-465. https://doi.org/10.1016/j.im.2008.06.007

Chughtai, A. A., \& Buckley, F. (2013). Exploring the impact of trust on research scientists' work engagement. Personnel Review, 42(4), 396-421. https://doi.org/10.1108/PR-06-2011-0097 
Clercq, D. de, Dimov, D., \& Thongpapanl, N. (2013). Organizational Social Capital, Formalization, and Internal Knowledge Sharing in Entrepreneurial Orientation Formation. Entrepreneurship Theory and Practice, 37(3), 505-537. https://doi.org/10.1111/etap.12021

Coleman, J. (1990). Foundations of social theory (Vol. 3). Cambridge, Mass.: Harvard university press.

Compton, M. E., \& Meier, K. J. (2016). Managing social capital and diversity for performance in public organizations. Public Administration, 94(3), 609-629. https://doi.org/10.1111/padm.12237

Crawford, E. R., LePine, J. A., \& Rich, B. L. (2010). Linking job demands and resources to employee engagement and burnout: A theoretical extension and meta-analytic test. The Journal of Applied Psychology, 95(5), 834-848. https://doi.org/10.1037/a0019364

Dess, G. G., \& Shaw, J. D. (2001). Voluntary turnover, social capital, and organizational performance. Academy of Management Review, 26(3), 446-456. https://doi.org/10.5465/AMR.2001.4845830

Dillman, D. A., Smyth, J. D., \& Christian, L. M. (2014). Internet, phone, mail, and mixed-mode surveys: The tailored design method (4th ed.). Hoboken: John Wiley \& Sons. Retrieved from http://lib.myilibrary.com/detail.asp?id=635742

Edmondson, A. C., \& Roloff, K. S. (2008). Overcoming Barriers to Collaboration: Psychological Safety and Learning in Diverse Teams. In E. Salas, G. F. Goodwin, \& C. S. Burke (Eds.), The organizational frontiers series. Team effectiveness in complex organizations: Crossdisciplinary perspectives and approaches (pp. 183-208). New York: Routledge.

Ellis, A. P. J. (2006). System Breakdown: The Role of Mental Models and Transactive Memory in the Relationship between Acute Stress and Team Performance. Academy of Management Journal, 49(3), 576-589. https://doi.org/10.5465/amj.2006.21794674

Erikson, K. (1986). On Work and Alienation. American Sociological Review, 51(1), 1-8. https://doi.org/10.2307/2095474

George, B., \& Pandey, S. K. (2017). We Know the Yin-But Where Is the Yang?: Toward a Balanced Approach on Common Source Bias in Public Administration Scholarship. Review of Public Personnel Administration, 37(2), 245-270. https://doi.org/10.1177/0734371X17698189

Halbesleben, J. R. B. (2010). A meta-analysis of work engagement: Relationships with burnout, demands, resources, and consequences. In A. B. Bakker \& M. P. Leiter (Eds.), Work Engagement: A Handbook of Essential Theory and Research (pp. 102-117). Taylor \& Francis.

Hallberg, U. E., \& Schaufeli, Wilmar. (2006). "Same Same" But Different? European Psychologist, 11(2), 119-127. https://doi.org/10.1027/1016-9040.11.2.119

Hayes, A. F. (2009). Beyond Baron and Kenny: Statistical Mediation Analysis in the New Millennium. Communication Monographs, 76(4), 408-420. https://doi.org/10.1080/03637750903310360

Holme, J. J., \& Rangel, V. S. (2012). Putting School Reform in Its Place: Social Geography, Organizational Social Capital, and School Performance. American Educational Research Journal, 49(2), 257-283. https://doi.org/10.3102/0002831211423316 
Hummel, R. P. (1994). The bureaucratic experience: A critique of life in the modern organization. New York: St Martin's.

Inkpen, A. C., \& Tsang, E. W. K. (2005). Social Capital, Networks, and Knowledge Transfer. The Academy of Management Review, 30(1), 146-165. https://doi.org/10.2307/20159100

James, L. R. (1982). Aggregation bias in estimates of perceptual agreement. Journal of Applied Psychology, 67(2), 219-229. https://doi.org/10.1037/0021-9010.67.2.219

Janis, I. L. (1982). Groupthink: Psychological studies of policy decisions and fiascoes (Vol. 2). New York: Houghton Mifflin.

Kashy, D. A., \& Snyder, D. K. (1995). Measurement and data analytic issues in couples research. Psychological Assessment, 7(3), 338-348. https://doi.org/10.1037/1040-3590.7.3.338

Kenny, D. A., Mannetti, L., Pierro, A., Livi, S., \& Kashy, D. A. (2002). The statistical analysis of data from small groups. Journal of Personality and Social Psychology, 83(1), 126-137. https://doi.org/10.1037/0022-3514.83.1.126

Kim, Y.-C., \& Rhee, M. (2010). The Contingent Effect of Social Networks on Organizational Commitment: A Comparison of Instrumental and Expressive Ties in a Multinational HighTechnology Company. Sociological Perspectives, 53(4), 479-502. https://doi.org/10.1525/sop.2010.53.4.479

Knight, D., Pearce, C. L., Smith, Ken G., Olian, J. D., Sims, H. P., Smith, Ken A., \& Flood, P. (1999). Top management team diversity, group process, and strategic consensus. Strategic Management Journal, 20(5), 445-465. https://doi.org/10.1002/(SICI)10970266(199905)20:5<445::AID-SMJ27>3.0.CO;2-V

Kogut, B., \& Zander, U. (1996). What Firms Do?: Coordination, Identity, and Learning. Organization Science, 7(5), 502-518. https://doi.org/10.1287/orsc.7.5.502

Kozlowski, S. W. J., \& Klein, K. J. (2000). A multilevel approach to theory and research in organizations: Contextual, temporal, and emergent processes. In K. J. Klein \& S. W. J. Kozlowski (Eds.), Frontiers of industrial and organizational psychology: Vol. 12. Multilevel theory, research, and methods in organizations: Foundations, extensions, and new directions (pp. 3-90). San Francisco: Jossey-Bass.

Kristof-Brown, A. L.M.Y., Zimmerman, R. D., \& Johnson, E. C. (2005). Consequences of individuals' fit at work: A meta-analysis of person-job, person-organization, person-group, and person-supervisor fit. Personnel Psychology, 58(2), 281-342. https://doi.org/10.1111/j.1744-6570.2005.00672.x

Kroll, A., \& Tantardini, M. (2019). Motivating and Retaining Government Employees: The Role of Organizational Social Capital. International Public Management Journal, 22(2), 232-253. https://doi.org/10.1080/10967494.2017.1367341

LaHuis, D. M., Hartman, M. J., Hakoyama, S., \& Clark, P. C. (2014). Explained Variance Measures for Multilevel Models. Organizational Research Methods, 17(4), 433-451. https://doi.org/10.1177/1094428114541701

Leana, C. R., \& Pil, F. K. (2006). Social Capital and Organizational Performance: Evidence from Urban Public Schools. Organization Science, 17(3), 353-366. https://doi.org/10.1287/orsc.1060.0191 
Leana, C. R., \& Van Buren III, H. J. (1999). Organizational Social Capital and Employment Practices. Acacemy of Management Review, 24(3), 538-555. Retrieved from https://www.jstor.org/stable/pdf/259141.pdf

Lewis, K. (2003). Measuring transactive memory systems in the field: scale development and validation. Journal of Applied Psychology, 88(4), 587.

Loi, R., Hang-Yue, N., \& Foley, S. (2006). Linking employees' justice perceptions to organizational commitment and intention to leave: The mediating role of perceived organizational support. Journal of Occupational and Organizational Psychology, 79(1), 101120. https://doi.org/10.1348/096317905X39657

Lowe, R. H., \& Vodanovich, S. J. (1995). A field study of distributive and procedural justice as predictors of satisfaction and organizational commitment. Journal of Business and Psychology, 10(1), 99-114. https://doi.org/10.1007/BF02249273

Marks, M. A., Sabella, M. J., Burke, C. S., \& Zaccaro, S. J. (2002). The impact of cross-training on team effectiveness. Journal of Applied Psychology, 87(1), 3.

Maslach, C., Schaufeli, W., \& Leiter, M. P. (2001). Job burnout. Annual Review of Psychology, 52, 397-422. https://doi.org/10.1146/annurev.psych.52.1.397

Mathieu, J. E., \& Zajac, D. M. (1990). A review and meta-analysis of the antecedents, correlates, and consequences of organizational commitment. Psychological Bulletin, 108(2), 171-194. https://doi.org/10.1037/0033-2909.108.2.171

Meyer, J. P., \& Allen, N. J. (1991). A three-component conceptualization of organizational commitment. Human Resource Management Review, 1(1), 61-89. https://doi.org/10.1016/1053-4822(91)90011-Z

Meyer, J. P., Allen, N. J., \& Smith, C. (1993). Commitment to Organizations and Occupations: Extension and Test of a Three-Component Conceptualization. Journal of Applied Psychology, 78(4), 538-551.

Meyer, J. P., Stanley, D. J., Herscovitch, L., \& Topolnytsky, L. (2002). Affective, Continuance, and Normative Commitment to the Organization: A Meta-analysis of Antecedents, Correlates, and Consequences. Journal of Vocational Behavior, 61(1), 20-52.

https://doi.org/10.1006/jvbe.2001.1842

Miller, G. J. (1992). Managerial dilemmas: The political economy of hierarchy. New York: Cambridge University Press.

Mohammed, S., Ferzandi, L., \& Hamilton, K. (2010). Metaphor No More: A 15-Year Review of the Team Mental Model Construct. Journal of Management, 36(4), 876-910. https://doi.org/10.1177/0149206309356804

Morgeson, F. P., \& Humphrey, S. E. (2006). The Work Design Questionnaire (WDQ):

Developing and validating a comprehensive measure for assessing job design and the nature of work. The Journal of Applied Psychology, 91(6), 1321-1339. https://doi.org/10.1037/00219010.91.6.1321

Morrow, V. (1999). Conceptualising Social Capital in Relation to the Well-Being of Children and Young People: A Critical Review. The Sociological Review, 47(4), 744-765. https://doi.org/10.1111/1467-954X.00194

Mowday, R. T., Koberg, C. S., \& McArthur, A. W. (1984). The Psychology of the Withdrawal Process: A Cross-Validation Test of Mobley's Intermediate Linkages Model of Turnover in 
Two Samples. Academy of Management Journal, 27(1), 79-94.

https://doi.org/10.2307/255958

Moynihan, D. P., \& Pandey, S. K. (2006). Creating desirable organizational characteristics. Public Management Review, 8(1), 119-140. https://doi.org/10.1080/14719030500518899

Nahapiet, J., \& Ghoshal, S. (1998). Social Capital, Intellectual Capital, and the Organizational Advantage. The Academy of Management Review, 23(2), 242-266. https://doi.org/10.2307/259373

Nyhan, R. C. (1999). Increasing Affective Organizational Commitment in Public Organizations. Review of Public Personnel Administration, 19(3), 58-70. https://doi.org/10.1177/0734371X9901900305

Özaralli, N. (2003). Effects of transformational leadership on empowerment and team effectiveness. Leadership \& Organization Development Journal, 24(6), 335-344. https://doi.org/10.1108/01437730310494301

Portes, A., \& Sensenbrenner, J. (1993). Embeddedness and Immigration: Notes on the Social Determinants of Economic Action. American Journal of Sociology, 98(6), 1320-1350.

Putnam, R. D. (1995). Bowling Alone: America's Declining Social Capital. Journal of Democracy, 6(1), 65-78. https://doi.org/10.1353/jod.1995.0002

Raub, S., \& Blunschi, S. (2014). The Power of Meaningful Work. Cornell Hospitality Quarterly, 55(1), 10-18. https://doi.org/10.1177/1938965513498300

Rentsch, J. R. (1990). Climate and culture: Interaction and qualitative differences in organizational meanings. Journal of Applied Psychology, 75(6), 668-681. https://doi.org/10.1037/0021-9010.75.6.668

Rentsch, J. R., \& Klimoski, R. J. (2001). Why do 'great minds' think alike?: Antecedents of team member schema agreement. Journal of Organizational Behavior, 22(2), 107-120. https://doi.org/10.1002/job.81

Saks, A. M. (2006). Antecedents and consequences of employee engagement. Journal of Managerial Psychology, 21(7), 600-619. https://doi.org/10.1108/02683940610690169

Salas, E., Goodwin, G. F., \& Burke, C. S. (Eds.). (2008). The organizational frontiers series. Team effectiveness in complex organizations: Cross-disciplinary perspectives and approaches. New York: Routledge. Retrieved from http://site.ebrary.com/lib/alltitles/docDetail.action?docID=10442789

Schaufeli, Wilmar, \& Bakker, A. B. (2003). Utrecht work engagement scale: Preliminary manual. Utrecht: Occupational Health Psychology Unit, Utrecht University.

Schiff, M. (1992). Social Capital, Labor Mobility, and Welfare: The Impact of Uniting States. Rationality and Society, 4(2), 157-175. https://doi.org/10.1177/1043463192004002003

Sherif, K., Hoffman, J., \& Thomas, B. (2006). Can technology build organizational social capital? The case of a global IT consulting firm. Information \& Management, 43(7), 795-804. https://doi.org/10.1016/j.im.2006.07.001

Shteynberg, G., \& Galinsky, A. D. (2011). Implicit coordination: Sharing goals with similar others intensifies goal pursuit. Journal of Experimental Social Psychology, 47(6), 1291-1294. https://doi.org/10.1016/j.jesp.2011.04.012

Snijders, T. A. B., \& Bosker, R. J. (1994). Modeled Variance in Two-Level Models. Sociological Methods \& Research, 22(3), 342-363. https://doi.org/10.1177/0049124194022003004 
Strom, D. L., Sears, K. L., \& Kelly, K. M. (2014). Work Engagement: The Roles of Organizational Justice and Leadership Style in Predicting Engagement Among Employees. Journal of Leadership \& Organizational Studies, 21(1), 71-82. https://doi.org/10.1177/1548051813485437

Sundstrom, E., De Meuse, K. P., \& Futrell, D. (1990). Work teams: Applications and effectiveness. American psychologist, 45(2), 120.

Tantardini, M., \& Kroll, A. (2015). The Role of Organizational Social Capital in Performance Management. Public Performance \& Management Review, 39(1), 83-99. https://doi.org/10.1080/15309576.2016.1071163

Thompson, J. A. (2005). Proactive personality and job performance: A social capital perspective. The Journal of Applied Psychology, 90(5), 1011-1017. https://doi.org/10.1037/00219010.90.5.1011

Tsai, W., \& Ghoshal, S. (1998). Social Capital and Value Creation: The Role of Intrafirm Networks. The Academy of Management Journal, 41(4), 464-476. https://doi.org/10.2307/257085

Van Mierlo, H., Vermunt, J. K., \& Rutte, C. G. (2008). Composing Group-Level Constructs From Individual-Level Survey Data. Organizational Research Methods, 12(2), 368-392. https://doi.org/10.1177/1094428107309322

Vogel, D., \& Kroll, A. (2016). The Stability and Change of PSM-related Values across Time: Testing Theoretical Expectations against Panel Data. International Public Management Journal, 19(1), 53-77. https://doi.org/10.1080/10967494.2015.1047544

Walker, R. M., \& Brewer, G. A. (2008). An Organizational Echelon Analysis of the Determinants of Red Tape in Public Organizations. Public Administration Review, 68(6), 1112-1127. https://doi.org/10.1111/j.1540-6210.2008.00959.x

Willems, J. (2016). Building Shared Mental Models of Organizational Effectiveness in Leadership Teams Through Team Member Exchange Quality. Nonprofit and Voluntary Sector Quarterly, 45(3), 568-592. https://doi.org/10.1177/0899764015601244

Woehr, D. J., Loignon, A. C., Schmidt, P. B., Loughry, M. L., \& Ohland, M. W. (2015). Justifying Aggregation With Consensus-Based Constructs: A Review and Examination of Cutoff Values for Common Aggregation Indices. Organizational Research Methods, 18(4), 704-737. https://doi.org/10.1177/1094428115582090

Wong, S.-S. (2004). Distal and Local Group Learning: Performance Trade-offs and Tensions. Organization Science, 15(6), 645-656. https://doi.org/10.1287/orsc.1040.0080

Zhao, X., Lynch, J. G., \& Chen, Q. (2010). Reconsidering Baron and Kenny: Myths and Truths about Mediation Analysis. Journal of Consumer Research, 37(2), 197-206.

https://doi.org/10.1086/651257 


\section{Appendix: Measures}

\begin{tabular}{|c|c|}
\hline Variable & Operationalization \\
\hline $\begin{array}{l}\text { Engagement (adapted from } \\
\text { Schaufeli \& Bakker, 2003) } \\
(\alpha=.88)\end{array}$ & 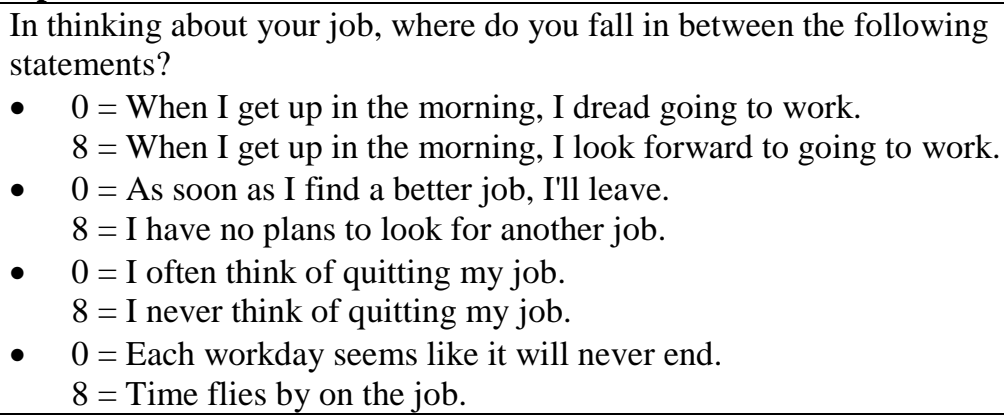 \\
\hline $\begin{array}{l}\text { Organizational Commitment } \\
\text { (adapted from Meyer et al., } \\
\text { 1993) }(\alpha=.82)\end{array}$ & $\begin{array}{l}\text { Thinking about how you feel about working for the City of }[\ldots] \text {, how } \\
\text { much do you agree or disagree... } \\
(0=\text { strongly disagree; } 6=\text { strongly agree }) \\
\text { - I would feel guilty if I left this organization now. } \\
\text { - I wouldn't leave this organization right now because I have a sense } \\
\text { of obligation to the people in it. } \\
\text { - I would be very happy to spend the rest of my career with this } \\
\text { organization. } \\
\text { In thinking about your job, where do you fall in between the } \\
\text { following statements? }(0=\text { I do not feel emotionally attached to } \\
\text { this organization; } 8=\mathrm{I} \text { am emotionally attached to this } \\
\text { organization.) }\end{array}$ \\
\hline Organizational social capital & 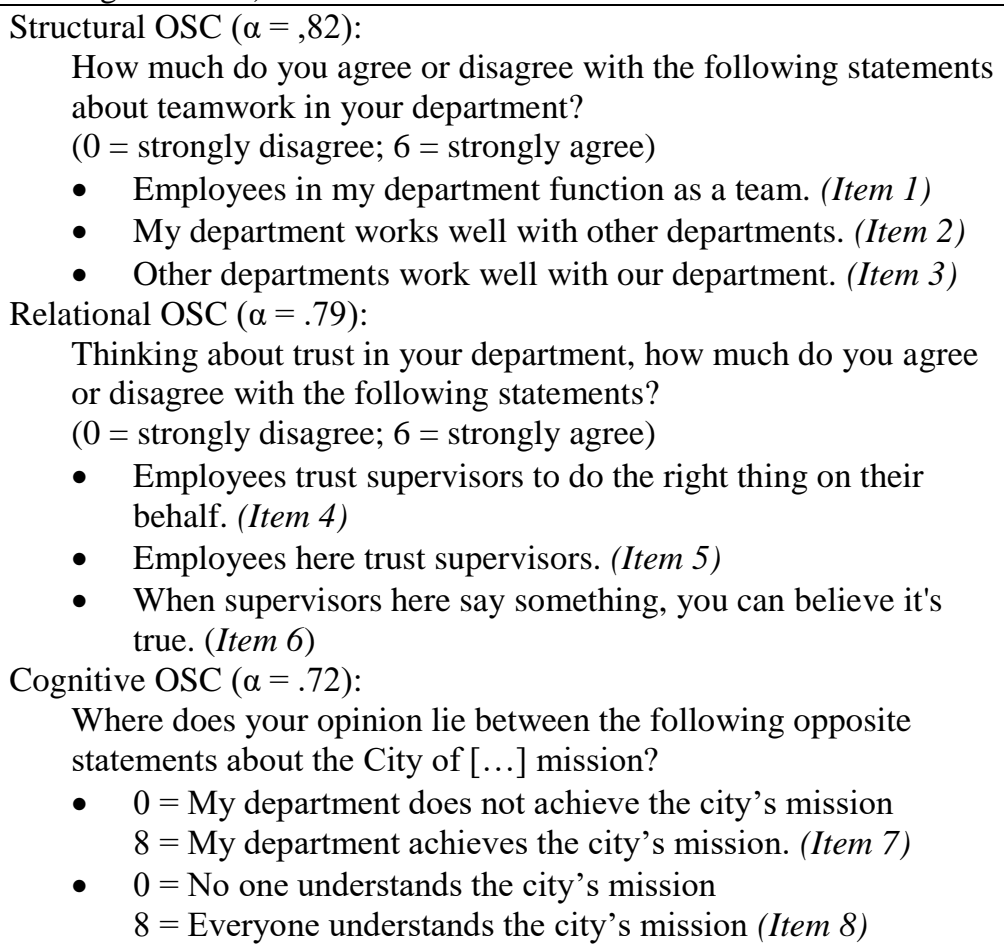 \\
\hline $\begin{array}{l}\text { Procedural Fairness (adapted } \\
\text { from Alexander \& Ruderman, } \\
\text { 1987) }(\alpha=.81)\end{array}$ & $\begin{array}{l}\text { In thinking about your input into department decisions, how much do } \\
\text { you agree or disagree with the following statements } \\
(0=\text { strongly disagree; } 6=\text { strongly agree }) \\
\text { - I have a lot of say in rules that affect my job. } \\
\text { - I have a lot of say in the city's rules. }\end{array}$ \\
\hline
\end{tabular}


- I am given the chance to contribute to important decisions made about my department.

Satisfaction with working environment $(\alpha=.78)$
How satisfied or dissatisfied are you with the following parts of your job?

$(0=$ strongly disagree $; 6=$ strongly agree $)$

- The extent to which my work environment embraces new ideas

- The opportunities I have for professional development (training, learning opportunities)

- The access I have to technology

- The feeling that I have accomplished worthwhile work

\begin{tabular}{|c|c|}
\hline Autonomy $(\alpha=.76)$ & $\begin{array}{l}\text { In thinking about your job, how much do you agree or disagree with } \\
\text { the following statements? } \\
(0=\text { strongly disagree; } 6=\text { strongly agree }) \\
\text { - I feel that I am my own boss in most matters. } \\
\text { - Generally, I'm allowed to work independently in my job. } \\
\text { - I have the right amount of independence for my job. }\end{array}$ \\
\hline $\begin{array}{l}\text { Job Significance (Morgeson \& } \\
\text { Humphrey, 2006) }(\alpha=.87)\end{array}$ & $\begin{array}{l}\text { How much do you agree or disagree with these statements about your } \\
\text { job? } \\
(0=\text { strongly disagree; } 6=\text { strongly agree }) \\
\text { - The results of my work significantly affect the lives of other } \\
\text { people. } \\
\text { - My job has a large impact on citizens. } \\
\text { - My job itself is very important in the broader scheme of things. } \\
\text { The work I do on this job is meaningful to the citizens of the City } \\
\text { of }[\ldots] .\end{array}$ \\
\hline Education & $\begin{array}{l}\text { Which of the following represents your highest level of education? } \\
-\quad 0=\text { High School or GED } \\
-\quad 1=\text { Some College } \\
\text { - } \quad 2=\text { Bachelor's Degree } \\
-\quad 3=\text { Some Graduate School } \\
-\quad 4=\text { Graduate Degree }\end{array}$ \\
\hline Gender & $\begin{array}{l}\text { Are you } \ldots \\
0=\text { male } ; 1=\text { female }\end{array}$ \\
\hline Age & How old are you? \\
\hline Race & $\begin{array}{l}0=\text { non Caucasian } \\
1=\text { Caucasian }\end{array}$ \\
\hline Tenure & For how many years have you been working for the City of $[\ldots]$ ? \\
\hline
\end{tabular}

